\title{
A formação histórica do moderno direito privado português e brasileiro (1)
}

\author{
Guilherme Braga da Cruz \\ (Professor na Faculdade de Direito da \\ Universidade de Coimbra)
}

Quem queira compreender, cientificamente, as semeIhanças e diferenças que atualmente existem entre o direito português e o direito brasileiro, tem que remontar à época em que, nas duas pátrias irmãs, não vigorava senão um mesmo sistema jurídico, e acompanhar, passo por passo, desde então até os nossos dias, a evolução que as instituições jurídicas de Portugal e do Brasil foram sofrendo, ora acompanhando-se numa trajetória idêntica, ora diversificando-se em trajetórias diferentes, mais apegadas ou mais afastadas da tradição jurídica que lhes serviu de ponto de partida comum.

Propomo-nos, justamente, focar alguns aspectos dessa evolução, limitando, porém, o âmbito das nossas considerações ao campo do direito privado. É êsse, sem dúvida, o ramo do direito em que o problema oferece maior interêsse histórico-jurídico, pois é no domínio do direito privado que o pêso da tradição se faz sempre sentir mais intensamente, resistindo com maior eficácia aos embates das inovações propostas pelas novas correntes doutrinárias: o direito constitucional, o direito administrativo, o próprio direito penal, tanto em Portugal como no Brasil, puderam

(") Comunicação ao II." "Colloquium Internacional de Estudos Luso-Brasileiros", realizado em setembro de 1954, em comemoração do IV.o Centenário da cidade de São Paulo. 
fàcilmente ser objeto duma completa renovação, introduzida ex abrupto pelas reformas da época liberal, sem que, na execução de tais reformas, se suscitassem dificuldades de maior. A vitória de novas idéias políticas e econômicas, ou de novas correntes doutrinais, foi suficiente e para garantir, perante a quase total indiferença do povo, o êxito de radicais transformações introduzidas pelos poderes constituídos, nesses ramos do direito.

No campo do direito privado, pelo contrário, a penetração das novas idéias teve que defrontar uma tradição jurídica fortemente arraigada no espírito do povo, e nem sempre lhe foi fácil levar de vencida a resistência oposta por essa tradição. Algumas reformas mais arrojadas, que os legisladores precipitadamente introduziram, viram-se forçadas a arrepiar caminho e a deixar-se suplantar pelas velhas instituições jurídicas, que a breve trecho eram de novo postas em vigor, remoçadas e revitalizadas, como fénix renascida das próprias cinzas. Outras reformas de vulto só pôde o legislador abalançar-se a fazê-las ao cabo de intensa preparação doutrinal, levada a efeito, durante dezenas de anos, pelos jurisconsultos, que conseguiram, assim, através dum trabalho persistente e lento, criar para elas o ambiente propício. Outras alterações, finalmente, não se aventurou sequer o legislador a introduzí-las, apesar de insistentemente recomendadas por certos jurisconsultos progressistas, por verificar que não se adaptariam fàcilmente ao sentir unânime do povo.

Nada disto causa estranhesa se nos lembrarmos que o direito privado é, de todos os ramos do direito, o que mais ligado se encontra às realidades sociais, porque é à sombra dêle que se desenrola tôda a existência do homem, na sua luta pela vida e pela realização plena da sua personalidade. Os outros ramos do direito pode o homem sentilos e vivê-los, com maior ou menor intensidade; mas terá sempre, perante êle, a sensação de se tratar de algo de artificial e exterior a si mesmo, que lhe é imposto de fora para dentro, a bem da coletividade, isto é, a bem duma 
entidade abstrata, cujas exigências, muitas vêzes, não chega rigorosamente a compreender. $O$ direito privado pelo contrário, sente-o sempre o homem, ligado ao mais íntimo da sua vida e do seu ser; compreende-o como alguma coisa que brota naturalmente, de dentro de si mesmo, porque representa uma disciplina de vida, sem a qual não lhe serả possivel o convivio pacífico com os seus semelhantes, e sem a qual, portanto, não encontrará sequer a necessária proteção dos seus próprios interêsses.

É no campo do direito privado, por isso mesmo, que melhor se pode apreciar a presença do passado, dentro dos códigos modernos, pois não é fácil desenraizar do espírito do povo certas instituições seculares, ou modificá-las ràpidamente, ao sabor de novas concepções políticas, econômicas ou filosóficas. E é nesse domínio, portanto, que o historiador do direito pode prestar mais largo contributo para o bom entendimento das leis vigentes, mostrando o que nelas há de tradicional e de inovador, e qual a razão de ser dessas inovações ou dêsse respeito pela tradição.

\section{O direito privado português ao fim de setecentos}

A formação do moderno direito privado português e brasileiro é o produto dum longo processo evolutivo, cujo ponto de partida se pode fixar, com bastante rigor, nos meados do séc. XVIII. Para compreendermos o que foi êsse processo evolutivo, e para medirmos o verdadeiro alcance da luta travada, desde êsse momento, entre a tradição e as correntes inovadoras, procuraremos esboçar, antes de mais nada, a traços largos, o que era o direito privado português, no fim do segundo quartel de setecentos:

- Na base do sistema jurídico em vigor, encontravamse a essa data, as velhas Ordenações Filipinas, que constituíam, pelo menos teòricamente, a primeira de entre tôdas as fontes de direito. Divididas em 5 livros, à semelhança das anteriores Ordenações de D. Afonso V e de D. Manuel, consagravam expressamente ao direito privado o livro IV, 
além de preceitos isolados, esporàdicamente contidos nos restantes livros.

Promulgadas em 1603, durante v domínio castelhano em Portugal, e confirmadas por D. Joño IV em 1643, depois da Restauração da Independência, estas Ordenações apresentavam-se, porém, mais antiquadas e defeituosas do que poderia indicá-lo a sua "certidão de idade"

Apresentavam-se antiquadas, porque a preocupação de respeitar a tradição jurídica portuguêsa absorveu de tal forma o espírito dos seus compiladores - a fim de evitar possíveis descontentamentos que elas nasceram, pode dizer-se, já envelhecidas: em vez duma codificação progressiva e totalmente refundida, como as necessidades da época exigiam, as Ordenações Filipinas surgiram para a história como uma simples versão atualizada das Manuelinas, como estas já tinham sido uma simples atualização das Afonsinas. Modificadas na redação e na forma, as Ordenações de FiLipe II conservam, assim, em tôda a sua estrutura, o espírito das anteriores, constituindo, verdadeiramente, uma presença da Idade Média nos Tempos Modernos.

Mas, além de antiquadas, as Ordenações eram, sobretudo, defeituosas - A falta de clareza da linguagem, as contradições frequentes, a prolixidade dos preceitos legislativos, eram ainda, e apesar de tudo, os menores dos seus defeitos, pois a todos êles se vinha juntar - e êsse sim de enorme gravidade - o caráter extremamente lacunoso das suas disposições. Êsse defeito, patente em todos os cinco livros do nosso Código fundamental, é sobretudo notório no campo do direito privado: há capitulos inteiros do direito civil em que as Ordenações são totalmente omissas, e outros em que, só através de alguma disposição esporádica, se pode vislumbrar quais as idéias mestras que o legislador teve em mente.

A legislação extravagante complementar das Ordenaçôes, padecendo dos mesmos defeitos da legislação codificada, longe de remediar êste mal, só contribuía para o agravar. E daí a necessidade dum larguíssimo recurso ao 
direito subsidiário - o mesmo é que dizer, pràticamente, ao direito romano - para o preenchimento dessas lacunas e para o próprio entendimento das defeituosas disposições das leis pátrias.

O recurso ao direito romano, como fonte subsidiária, estava, aliás, autorizado pelas próprias Ordenações, que para êle remetiam expressamente a resolução dos casos omissos, com exceção daqueles que envolvessem matéria de pecado, e que deveriam, de preferência, ser resolvidos pelo direito canônico. E, como complemento do recurso ao direito romano, autorizavam ainda as Ordenações a utilização da Glosa de Acúrsio e das Opiniões de Bártolo, desde que não fôssem contrariadas pela opinião comum dos doutores.

0 quadro que acabamos de traçar era completado por uma literatura jurídica rotineira, e despida de elevação, integrada nos velhos moldes da escola dos comentadores, onde predominavam as obras de casuística, que mais pareciam destinadas a complicar os problemas que a esclarecê-los. Essa literatura jurídica usava e abusava do recurso ao direito romano, consentido pelas Ordenações, chegando abusivamente a invocá-lo contra o texto expresso das leis pátrias, ou forçando a interpretação destas num sentido mais consentâneo com a tradição romanista. Uma atitude dessas era, de resto, facilitada pelo princípio, que as próprias Ordenações não condenavam, da possibilidade de a lei ser revogada pelo seu desuso, ou, o que vale o mesmo, ser substituída por um costume de sentido contrário.

\section{As bases iniciais do moderno direito português}

E sôbre esta base que vai iniciar-se, a partir de meados do séc. XVIII, a formação do moderno direito pátrio. A obra de Luís António Verney - o Verdadeiro Método de Estudar - saída à luz da publicidade em 1746, marca, por assim dizer, a abertura dessa nova era, pois é a partir de então que começam a difundir-se em Portugal, em larga 
escala, as novas idéias do jusnaturalismo e do usus moder,nus pandectarum, que tão acentuados reflexos iriam ter na legislação do Marquês de Pombal, e que tão intensamente iriam desviar o rumo da evolução do direito privado português, dai em diante.

$\mathrm{E}$ a essas correntes jurisprudenciais vem depois acrescentar-se, a partir de fins do séc. XVIII e começos do séc. XIX, o individualismo crítico, que foi a expressão, no campo jurídico, do liberalismo político e do liberalismo econômico, difundidos por tôda a Europa a partir da Revolução Francesa, num "crescendo" avassalador de simpatia e de prestigio. Ora reforçando posições jurídicas já conquistadas pela escola do direito natural, ora cortando cerce alguns dogmas doutrinários dessa corrente jurídica, ora desvirtuando e interpretando em sentido diverso alguns dos seus princípios basilares, o individualismo liberal representa uma espécie de segunda camada de inovação, que, sobreposta às do jusnaturalismo, há-de operar, como "resultante", a formação do direito privado moderno.

\section{O jusnaturalismo e o individualismo dos fins do século XVIII e do começo do século XIX.}

Do que deixamos dito, já se infere que podemos distinguir dois periodos dentro do campo histórico que nos propomos analisar: um primeiro período, a que chamaremos do jusnaturalismo, que vai de meados do séc. XVIII até começos do séc. XIX; e um segundo período, a que chamamos do individualismo, que se inicia com a penetração das idéias liberais em Portugal, e que, verdadeiramente, só ganha vulto a partir de 1820 , depois da primeira revolta liberal vitoriosa. Por curiosa coincidência, o primeiro destes periodos é comum à história jurídica de Portugal e do Brasil; e o segundo corresponde à separação política das duas pátrias irmãs e à formação de rumos diversos na evolução das respectivas instituições jurídico-privadas. Esta coincidência histórica de datas entre a diversificação poli- 
tica das duas nações e a vitória de novas idéias políticas, econômicas e jurídicas, iria ter, como adiante demonstraremos, muito maior importância do que pode parecer à primeira vista, na formação do moderno direito privado de Portugal e do Brasil.

A introdução em Portugal das correntes doutrinárias do direito natural e do "usus modernus pandectarum"

O primeiro dos dois periodos apontados, comum à história jurídica das duas nações lusiadas, é caracterizado pela introdução, em Portugal, das correntes doutrinárias do direito natural e do usus modernus pandectarum. Estas duas correntes encontravam-se, aliás, estreitamente ligadas entre si, podendo afirmar-se que a segunda não era mais do que um reflexo da aplicação da primeira ao campo dos estudos romanísticos. Se a escola do direito natural preconizava a existência dum direito eterno e imutável, estruturado na razão humana, e igual, por isso mesmo, para todos os homens e para tôdas as épocas, a escola do usus modernus pandectarum preconizava um estudo do direito romano feito à luz dêsse direito natural de fundo racionalista.

Do velho direito contido no Corpus Juris Civilis, só devia aproveitar-se, como subsidiário das leis pátrias ou como elemento de interpretação das mesmas, aquilo que, por ser conforme ao direito natural, se revelava ser a expressão de princípios imutáveis e eternos, e manter, por isso mesmo, perene atualidade. Tudo o mais, deveria ser despresado, como expressão dum condicionalismo histórico para sempre desaparecido, e deveria ceder o passo às normas ditadas pelo condicionalismo político, econômico e social da época.

Isto equivale a dizer que o direito romano, ao contrário do que até então acontecia, não deveria ter, de per si, qualquer autoridade intrínseca, nem como elemento de interpretação, nem como elemento integrador de lacunas. Essa autoridade personificar-se-ia agora no direito natural, na 
recta ratio ou boa razão, onde o intérprete das leis ou o julgador deveriam ir inspirar-se para a resolução dos casos duvidosos ou omissos. O Corpu's Juris Civilis seria simplesmente um dos recursos, ao alcance do intérprete, para a determinação dessa recta ratio, mas sem maior autoridade do que qualquer outro, capaz de o encaminhar nesse mesmo sentido, como, por exemplo, a tradição jurídica nacional, o direito internacional ou das gentes, ou o próprio direito positivo vigente nas nações estrangeiras.

Foi desta linha de pensamento que derivaram as idéias mestras que iriam nortear tôda a evolução do direito privado nacional, na segunda metade do séc. XVIII: hostilidade, ou, pelo menos, prudente desconfiança perante o direito romano; sua utilização, como elemento de interpretação e integração das leis pátrias, nos restritos moldes preconizados pela escola do uso moderno; exaltação das tradições jurídicas nacionais, ou, que, pelo menos, se julgavam sê-lo; e recurso constante à lição dos direitos estrangeiros, especialmente nas matérias que exigiam uma regulamentação nova, por virtude do progresso econômico da época.

Para obrigar o direito nacional e enveredar por êste novo caminho, houve necessidade, por vêzes, de modificar diretamente, por via legislativa, as instituições vigentes. Mas, para a generalidade dos casos não foi preciso ir tão longe: bastou impor, legislativamente, novos critérios de interpretação e integração das lacunas da lei, e imprimir novas diretrizes ao ensino universitário da ciência do direito.

O primeiro sistema foi aquêle a que teve de recorrer-se quando houve necessidade de vencer a barreira oposta pela letra expressa das Ordenações ou da legislação extravagante que lhe servia de complemento. Foi assim que surgiram, durante o consulado do Marquês de Pombal, algumas leis francamente inovadoras, totalmente dominadas pelo espirito do século. Algumas introduziram inovações que iriam criar raizes definitivas no direito privado português; outras ficaram condenadas a uma vida efêmera, tendo sido sus- 
pensa, total ou parcialmente, ainda antes do fim do século XVIII, logo no reinado de D. MARIA I.

De entre as numerosas reformas legislativas assim introduzidas, cumpre destacar a que aboliu a escravidão dos negros no Continente, declarando livres todos os individuos nascidos em Portugal; a que sancionou a chamada equidade bartolina, por via da qual todos os prazos em vidas se deviam considerar automàticamente renovados, por morte do último enfiteuta, em favor dos seus legitimos herdeiros; a que cerceou a amplitude dos emprazamentos eclesiásticos; a que mandou submeter às regras do contrato de locação os emprezamentos modernos, de bens já cultivados; a que sancionou a admissibilidade dos contratos de usura, despresando a antiga condenação canônica de tais negócios e proibindo apenas os juros superiores a $6 \%$; a que fixou a ordem de preferências no concurso de credores; a que modificou tôda a regulamentação jurídica dos vínculos; e muitas mais, que não é possível totalmente enumerar.

Nenhuma dessas reformas, porém, adquiriu tanto vulto como aquela que atingiu a regulamentação jurídica do direito sucessório e que forma o conteúdo de várias leis pombalinas que se tornaram famosas, dominadas, tôdas elas, pela idéia de hostilidade à sucessão testamentária e endeusamento da sucessão legítima, como única forma de sucessão consentânea com a razão natural: - Pela lei de 25 de Junho de 1766, estabeleceram-se numerosos entraves à liberdade de testar, considerando-se nulos os testamentos feitos durante doença grave, excepto se os contemplados eram parentes próximos do testador, e considerando-se nulas, igualmente, tôdas as deixas testamentárias feitas em favor de quem redigiu o testamento ou de qualquer parente seu até o quarto grau, ou da Ordem religiosa ou corporação eclesiástica a que o mesmo escriba do testamento pertencesse.

- Pela famosa lei de 9 de Setembro de 1769, novas restrições se impunham à liberdade testamentária, restaurando-se a velha distinção medieval entre bens herdados 
dos antepassados e bens adquiridos pelo próprio trabalho ou indústria, e estabelecendo-se, quanto aos primeiros, uma indisponibilidade quase total, cujos beneficiários seriam os parentes próximos, até ao $4 .^{\circ}$ grau inclusive, contado segundo o direito canônico.

$\mathrm{Na}$ verdade, o testador só poderia dispor dêsses bens dentro do quadro restrito dêsses parentes: - Se tivesse filhos ou outros descendentes, poderia dispor dum terço, mas sòmente para contemplar um desses filhos ou descendentes; se os não tivesse, podia dispor da totalidade, mas também tão sòmente para "escolher entre os ditos parentes aquele, ou aqueles, que lhe fôssem mais gratos". A favor de estranhos, só poderia dispor com expresso consentimento dêsses parentes até o quarto grau - o mesmo é que dizer, com expressa renúncia dêstes aos seus próprios direitos. Apenas sôbre os bens de ganhadia a liberdade de testar subsistiria em moldes mais largos, podendo o testador dispor livremente da têrça parte, mesmo em favor de estranhos, se tivesse filhos ou outros descendentes, e dispor da totalidade de tais bens se apenas tivesse ascendentes ou colaterais.

Por fôrça ainda da mesma lei, ficariam privados de direitos sucessórios $a b$ intestato - inclusive na própria herança paterna ou materna - todos os que professassem em qualquer comunidade religiosa; seriam nulas e de nenhum efeito tôdas as disposições ou convenções destinadas a instituir a alma por herdeira; e estabelecia-se, para o pai de família, que contraísse segundas núpcias, a obrigação de prestar caução de indenidade, relativamente às legítimas dos filhos do primeiro matrimônio.

Pelo alvará de 9 de novembro de 1754, introduzia-se a importante inovação de que a posse civil dos bens constitutivos da massa hereditária passaria automàticamente aos herdeiros testamentários ou legitimos, logo no momento da morte do de cujus, e independentemente de qualquer aceitação. Era a famosa regra le mort saisit le vif que o 
direito francês sempre conhecera, mas que o nosso direito, na esteira do direito romano, tinha rejeitado até então.

E, finalmente, pelas leis de 17 de agôsto de 1761 e de 4 de fevereiro de 1765 , restabelecia-se o velho princípio germânico do direito de masculinidade, embora limitado à linha reta descendente, e apenas a respeito de certas sucessões nas casas fidalgas do Reino, ordenando-se a total preterição das filhas pelos filhos, na partilha da herança paterna.

Na sua maior parte, êstes preceitos das leis pombalinas sôbre direito sucessório eram de tal forma avessos à tradição jurídica portuguêsa, que tinham fatalmente de sossobrar, como sossobraram, logo que terminou o Consulado do Marquês; mas dêles, contudo, alguma coisa ficou de definitivo, como melhor veremos adiante. A regra le mort saisit le vif, por exemplo, com tôdas as importantes consequências que dela derivam, nunca mais foi abandonada pelo direito português e brasileiro; e o fetichismo romano da sucessão testamentária, pelo menos no domínio dos princípios gerais, ficou para sempre abalado, desde então, tanto em Portugal como no Brasil.

\section{O marco miliário da Lei da Boa Razão e as reformas pombalinas}

Se a adaptação da letra expressa das Ordenações ou das leis extravagantes à nova linha de pensamento exigiu, como acabamos de ver, a introdução de importantes reformas legislativas, a tarefa tornou-se, porém, muito mais fácil, naquele vastíssimo domínio onde pontificavam, pela deficiência das leis nacionais, o recurso ao direito subsidiário, ou onde a atividade interpretativa era chamada a atuar, com ampla liberdade de movimentos. Aqui, para que tudo sofresse uma radical transformação, bastava que uma providência legislativa viesse impor novos critérios de interpretação e de integração das lacunas da lei, inspirados nas modernas correntes doutrinárias. E foi o que veio a ser feito, 
no auge do domínio pombalino, com a promulgação da famosa lei de 18 de agôsto de 1769, que havia de ser crismada, na época liberal, com o nome, ainda hoje consagrado, de "Lei da Boa Razão".

Verdadeiro marco miliário na história jurídica de Portugal e do Brasil, a Lei da Boa Razão começa por fixar doutrina sôbre a interpretação autêntica das leis, dizendo em que casos pode e deve a Casa da Suplicação, tribunal supremo do Reino, proferir assentos com valor normativo, e pondo cobro ao abuso, que se tinha generalizado, de atribuir idêntico valor aos assentos de outros tribunais superiores.

Logo em seguida, a lei de 18 de agôsto de 1769 , fixa as normas a que deve obedecer a integração das lacunas da lei, indicando quais as fontes subsidiárias que é lícito utilizar nos casos omissos. O seu primeiro cuidado, a êste respeito, é o de reprimir o abuso, até aí tão vulgarizado, de recorrer aos textos de direito romano ou a outros textos doutrinais, com despreso do disposto, em sentido diverso, pelo direito nacional. Proibe-se, com efeito, que nas alegações ou decisões judiciais, se faça uso de quaisquer textos, ou se invoque a autoridade de algum escritor, enquanto houver determinação expressa das Ordenações, das leis pátrias, ou dos usos do Reino legitimamente aprovados.

Só perante a insuficiência dessas fontes é lícito o recurso ao direito subsidiário. Mas êste direito subsidiário já não será agora, como era anteriormente, o direito romano em si mesmo considerado: será antes a boa razão (a recta ratio da escola jusnaturalista) onde quer que ela se encontre, seja nas leis romanas, seja no direito das gentes, seja nas próprias leis positivas das nações estrangeiras.

Essa boa razão pode ir procurar-se, sem dúvida, e antes de mais nada, aos textos do direito romano, ou melhor e para nos servirmos das próprias palavras da lei - àquelas "verdades essenciais, intrínsecas e inalteráveis, que a ética dos mesmos romanos havia estabelecido, e que os direitos divinos e humanos formalizaram, para servirem de regras 
morais e civis entre o Cristianismo". Mas poderá ir buscarse, igualmente, acrescenta logo a lei, àquelas "outras regras, que, de unânime consentimento, estabeleceu o direito das gentes, para direção e govêrno de tôda as nações civilizadas". E nada impede, por último, que a mesma boa razão se vá procurar àquilo "que se estabelece nas leis políticas, econômicas, mercantís e marítimas, que as mesmas nações cristãs têm promulgado!".

Neste último ponto, a lei da Boa Razão é mais enérgica ainda, pois não contente em colocar essas leis estrangeiras a par do direito romano e do direito das gentes, como uma das possíveis expressões da recta ratio, volta com elas à carga, para dizer que, nessas matérias políticas, econômicas, mercantis e marítimas, é "muito mais racional e muito mais coerente" que se recorra ao subsídio "das sobreditas leis das nações cristãs, iluminadas e polidas" do que ao subsídio das leis romanas. $E$ esta disposição sempre foi entendida pelos intérpretes, dai em diante, como totalmente impeditiva da aplicação subsidiária do direito romano, em tais matérias.

Em complemento destas disposições, a famosa lei de 1769 determina ainda que o direito canônico, como tal, deixe de ter aplicação subsidiária nos tribunais civis, revogando, assim, aquêle preceito das Ordenações que mandava preferir o direito canônico ao direito romano, como fonte subsidiária, quando a aplicação dêste acarretava pecado. E, do mesmo modo, manda banir, para sempre, a aplicação da Glosa de Acúrsio e dos Comentários de Bártolo, que as Ordenações consideravam também fontes subsidiárias, ao lado do direito romano e do direito canônico.

Não menos interessantes que estas regras, relativas à integração das lacunas da lei, são as disposições que a Lei da Boa Razão consagrou à fixação dos critérios para a interpretação das leis pátrias. Condena a lei, em longo arrazoado, o critério de interpretação que na prática se tinha estabelecido - por fôrça do qual as leis pátrias se deviam interpretar restritivamente, quando fôssem contrárias ao 
disposto nos textos romanos, e se deviam alargar ou interpretar extensivamente, quando lhes fôssem favoráveis. E declara, em seguida, que o disposto nas leis nacionais pode, na verdade, ampliar-se ou restringir-se, por via interpretativa, mas com base noutros critérios, substancialmente diversos daquele. Podem considerar-se lícitas, por exemplo "as restrições e ampliações que necessàriamente se deduzem do espírito das leis, significado pelas palavras delas tomadas no seu genuino e natural sentido". Licitas serão ainda, em segundo lugar, as interpretações extensivas ou restritivas "que se reduzirem aos princípios acima declarados", isto é, que se fundamentarem nos principios da boa razão tal como a lei anteriormente os definiu, ao abordar o problema da integração de lacunas. E, finalmente, serão admitidas também as ampliações e restrições deduzidas "por identidade de razão ou por fôrça de compreensão", ou seja, como hoje diríamos, por analogia ou a fortiori.

A obra reformadora da Lei da Boa Razão, neste domínio da interpretação das leis e integração das suas lacunas, seria completada, três anos mais tarde, com a Grande Reforma do ensino universitário, que é a mais perfeita expressão, no campo pedagógico, do despotismo esclarecido, que então nos governava. Os Novos Estatutos da Universidade, publicado em 1772 sob a inspiração do Marquês de Pombal, são realmente, no que toca ao ensino jurídico, o natural complemento do disposto na famosa lei de 18 de agôsto. São êsses Estatutos que, introduzindo no ensino universitário as idéias do jusnaturalismo e do usus modernus pandectarum, hão-de tornar possivel o que a Lei da Boa Razão, só por si, não conseguiria fàcilmente: a criação duma mentalidade diferente, nas novas gerações de juristas — duma mentalidade devidamente adaptada à compreensão do novo espírito que dominava a legislação portuguêsa, e, sobretudo, adaptada aos novos métodos de interpretação e integração das lacunas da lei, que se desejava fazer vingar na jurisprudência e na doutrina. 
Compreende-se, assim, que os Estatutos Pombalinos da Universidade tenham tido um cuidado extremo em pormenorizar os critérios a que o ensino do direito romano devia agora obedecer, no sentido de só se aproveitar dêle o que pudesse ser uma expressão da recta ratio. As disposições dos Estatutos tiveram, neste aspecto, um enorme alcance prático, pois foram sempre consideradas como verdadeiros esclarecimentos, de valor normativo, colocados ao dispor dos juristas e dos práticos do direito, para o bom entendimento dos preceitos da Lei da Boa Razão. Fixa-se aí, na verdade, uma série de regras, cuja observância poderá ajudar o intérprete a determinar se os preceitos do direito romano estão ou não de acôrdo com a boa razão, e se, portanto, são ou não suscetíveis de aplicação prática, em subsídio das leis nacionais. E, depois disso, para a hipótese de tais regras, apesar de tudo, não serem suficientes, e ficarem ainda dúvidas, no espírito dos intérpretes, a respeito da conformidade entre as leis romanas e a boa razão, fornecem os Estatutos um último critério de ordem prática: "Indagarão - lê-se neles expressamente - o uso moderno das mesmas leis romanas entre as sobreditas nações, que hoje habitam a Europa. E descobrindo que elas as observam e guardam ainda no tempo presente, terão as mesmas leis por aplicáveis". E "para se instruirem no dito uso moderno - acrescenta-se ainda - se aproveitarão os professôres do útil e apreciável trabalho, que para o mesmo fim se acha já feito por grande número de jurisconsultos, em diferentes livros".

Isto equivalia, numa palavra, a dar valor normativo, como fontes subsidiárias, para esclarecimento e entendimento das leis romanas, às obras doutrinais dos grandes corifeus da escola do uso moderno das pandectas, como Carpzov, Heineccius, Thomasius, Struve, Stryck, Böhmer, etc. Tratava-se, por isso mesmo, duma disposição de certo modo perigosa, porque, sendo muitas vêzes divergentes as opiniões dêstes autores, corria-se o risco de introduzir um grau acentuado de incerteza e instabilidade na jurispru- 
dência dos tribunais portuguêses. Mas, apesar de tudo, valeu a pena correr o risco, pois foi a utilização dessas grandes obras doutrinais que permitiu dar realização prática ao sopro de renovação jurisprudencial insuflado pela Lei da Boa Razão e pelos Estatutos da Universidade.

Quem queira certificar-se de como essa renovação efeivamente se operou - renovação profunda, substancial, por vêzes até totalmente inovadora - percorra com atenção a literatura jurídica da época e a nova jurisprudência dos tribunais. Não o poderemos fazer nós aqui, com o cuidado que o assunto requer, dados os limites que propositadamente desejámos impor a êste trabalho. Apenas a uma ou outra inovação de maior vulto nos referiremos adiante, para melhor nos apercebermos das relações entre esta época e a que imediatamente se segue, na formação do moderno direito privado português e brasileiro. Não queremos, no entanto, deixar de chamar a atenção para dois expoentes, bem expressivos, desta renovação a que estamos a referir-nos: a obra de Melo Freire, no domínio da literatura jurídica, e os assentos da Casa da Suplicação, no domínio da atividade jurisprudencial.

Nas Institutiones Juris Civilis Lusitani, de PAscoal José DE Melo Freire - verdadeiro padrão duma época, na história do direito português - difícil será encontrar um capítulo onde o espírito do direito natural e do usus modernus pandectarum não se encontre presente. E essa obra, pelo prestígio alcançado na cátedra universitária e na praxe dos tribunais, havia de contribuir, mais que nenhuma outra obra doutrinal, para a difusão e a aceitação daquela nova linha de pensamento.

Nos assentos da Casa da Suplicação - que tinham, não se esqueça, verdadeiro valor de leis - vamos encontrar, por seu turno, uma expressão eloquente do franco acolhimento que as novas idéias conseguiam conquistar, na atividade dos tribunais. O Tribunal Supremo do Reino, na delicada tarefa da interpretação autêntica das leis, não cessa de subordinar-se aos princípios jusnaturalistas e pan- 
dectistas ditados pela lei da Boa Razão e pelos Estatutos Pombalinos.

Num assento de 23 de novembro de 1769 , por exemplo, apressa-se a Casa da Suplicação a fixar doutrina sôbre o preceito das Ordenações que exigia escritura pública para os contratos de dívida que excedessem a quantia de sessenta mil réis, dizendo que tal exigência não tem que aplicarse aos mercadores e homens de negócio, porque "as suas obrigações, procurações e formas delas, não havendo sido tratadas, reguladas e decididas pelas leis deste Reino, se devem sòmente regular pelas leis maritimas e comerciais da Europa iluminada, pelo direito das gentes, e costumes louváveis e geralmente praticados pelas nações comerciais da mesma Europa".

Num outro assento, de 1772, para fixar doutrina sôbre o direito de alimentos, recorre a Casa da Suplicação a um longo arrazoado de considerações jusnaturalistas. 0 direito de exigir alimentos é apresentado como uma exceção à regra de que "cada um se deve alimentar e sustentar a si mesmo" - regra que aí se diz ser "um preceito geral de todos os direitos, natural, divino e humano". Quanto aos filhos e demais descendentes, a excepção deriva diretamente do direito natural, "porque, como os pais lhe deram o o ser e a vida, dita a razão natural que sejam obrigados a conservarem-lha". Mas, quanto aos ascendentes, já não sucede assim: o assento entende que a obrigação de os alimentar não é "obrigação perfeita e de rigorosa justiça", "nos puros têrmos do direito natural", mas tão sòmente uma obrigação imposta "pela fôrça e vigor que uniformemente lhe deram as leis civis", e que só por êsse motivo deve continuar a respeitar-se. E a respeito dos irmãos, menos ainda o direito natural impõe qualquer obrigação "que não seja de pura caridade". 0 assento reconhece que a obrigação de alimentos, quanto a êles, foi uma criação da Glosa, logo seguida depois por BÁrTolo "e pelo comum dos doutores", e, se acaba por ordenar que tal obrigação continui a respeitar-se, não é porque seja devido qualquer acatamento 
àquelas autoridades, mas apenas porque essa doutrina conseguiu, apesar de tudo, "prevalecer geralmente em tôdas as nações civilizadas dos últimos séculos" e se encontra, portanto, "munida com o uso moderno e geral das ditas Nações".

Num outro assento de 1780 , a Casa da Suplicação invoca o direito natural para dizer que só por sentença passada em julgado, e nunca por efeito automático, pode ter lugar a pena de deserção que as Ordenações impunham ao cônjuge que, tendo descendentes menores, deixasse de fazer inventários por morte do outro cônjuge. E em 1786, fixa-se, por meio dum assento, uma interpretação extensiva da lei, invocando-se "identidade de razão e fôrça de compreensão", nos precisos têrmos que a Lei de 18 de agôsto de 1769 tinha estabelecido.

Não menos curioso, também, é um assento de 2 de março de 1786 , onde se afirma que a constituição imperial de Zeñ̃o, relativa aos embargos de obra nova, não pode limitar o disposto em certo passo das Ordenações, porque a lei de 18 de agôsto de 1769 "aboliu tôdas as restrições que se deduzem dos textos do direito civil dos romanos",

Além da resolução de casos concretos, dentro da nova orientação doutrinária do jusnaturalismo e do usus modernus pandectarum, nota-se, nos Assentos desta época, uma grande preocupação de formular princípios gerais, relativos à interpretação e aplicação das leis vigentes. Na sua maior parte, êsses princípios não constituíam novidade, pois eram seguidos, de há muito, pelos nossos tribunais; e alguns dêles eram até de procedência romana. Mas o que é digno de registo, apesar de tudo, é o cuidado que o Tribunal Supremo agora tem em os formular através de assentos doutrinais, dando-lhes, portanto, valor normativo, e formando com êles um precioso quadro de regras de interpretação, em complemento das que se achavam fixadas na lei da Boa Razão e nos Estatutos da Universidade.

Assim, por exemplo, o princípio da não retroatividade das leis seria definido expressamente por um assento de 
23 de novembre de 1769 e confirmado depois por um outro assento do ano imediato.

Nesse mesmo ano de 1.770 , aparece definida em assento normativo a velha regra de que o intérprete não deve distinguir onde as leis não distinguem, regra que há-de ser novamente formulada num assento de 23 de juho de 1811.

Vem em seguida, na ordem cronológica, a regra aliás já implícita na lei da Boa Razão — de que "a lei compreende todos aquêles casos que cabem na sua razão e no seu espírito", definida expressamente nestes têrmos por um assento de 1774.

Um outro assento, de 1778, estabelece a doutrina de que "a graça do Príncipe sempre se entende sem prejuizo de terceiro", sancionando, assim, um antigo principio de procedência romana.

E, finalmente, em 1786, assentava-se na Casa da Suplicação a doutrina de que "o bem público atrai a si os casos omissos" e que deve, portanto, ser interpretada extensivamente "a lei ou constituição do príncipe que tem por objeto o maior cômodo da República".

A diversificação evolutiva das instituições jurídico-privadas de Portugal e do Brasil.

Cremos ter esboçado assim, tanto quanto o permitem as reduzidas proporções dêste trabalho, o que foi a evolução do nosso direito, na última época em que Portugal e o Brasil tiveram uma história jurídica comum. Se alguma coisa há de característico nesse período, é a subordinação de tôdas as inovações de ordem legislativa ou de ordem doutrinal a uma linha de pensamento filosófico bem definida e inequivocamente formulada. Nem sempre, é certo, se marchou com absoluta segurança, pois houve necessidade, por vêzes, de ir tateando o terreno, e ir emendando erros antes cometidos, na precipitação das inovações. Mas, quando houve sinuosidades na linha evolutiva das instituições jurídicas, não se ficaram elas devendo a qualquer falta de 
firmeza dos principios, mas antes a hesitações ou dificuldades na sua interpretação ou na sua aplicação prática.

Neste aspecto, a época do jusnaturalismo contrasta entre nós, abertamente, com a que vai seguir-se: - com a difusão das idéias liberais, e sobretudo com a sua primeira vitória no domínio político, abre-se uma nova era na história do nosso direito, que coincide cronològicamente como já dissemos atrás - com a separação política das duas nações lusíadas. Direito português e direito brasileiro começarão agora a trilhar caminhos diferentes, partindo do substrato comum que a época anterior lhes legara. Mas nesses novos e diferentes caminhos, terão ambos de sofrer as consequências dum condicionalismo histórico deveras ingrato, onde se faz sentir a falta duma firme orientação filosófica, capaz de disciplinar a luta que se travava entre as novas idéias politicas, sociais e econômicas e as instituições tradicionais.

As primeiras décađas da época liberal foram, na verdade, para a evolução das instituições jurídicas, uma época de desorientação, em que as reformas se sucederam um pouco ao sabor dos acontecimentos, e em que os jurístas procuraram adaptar ao direito nacional preceitos e idéias novas, que encontravam nos Códigos estrangeiros de recente promulgação, e cuja inspiração filosófica, muitas vêzes, não chegavam a compreender. "Lutavam entre si - diz expressivamente o professor CABRAL DE Moncada -, numa batalha em que não intervinha a mais leve disciplina filosófica, idéias revolucionárias espalhadas pela Revolução Francesa, tradições escolásticas, reminiscências jusnaturalistas do séc. XVIII, racionalistas e sensualistas, crenças religiosas, novas idéias econômicas, e atẻ um certo bom-senso de condescendências práticas, inspirado algumas vêzes em idéias inglêsas, que pretendia harmonizar com a tradição histórica determinadas reivindicações dos tempos modernos". 
Esta desorientação, no entanto, iria produzir-se muito mais intensamente em Portugal que no Brasil, o que, aliás, é perf eitamente compreensivel: - Situado na velha Europa, na vizinhança imediata dos países donde sopravam'as doutrinas inovadoras, Portugal tinha forçosamente que sentir, mais enèrgicamente que o Brasil, a influência dessas doutrinas. Vítima por outro lado, de agitações políticas muito mais intensas e muito mais graves que as verificadas na jovem nação irmã, o velho tronco lusitano tinha que sofrer também mais fortemente as consequências da luta apaixonada entre a tradição histórica e as novas idéias doutrinais. $\mathrm{E}$, para o quadro ser completo, não faltou até, nesta época, uma diferença sensível entre a formação científica dos juristas dos dois países, que se traduziu num maior irrequietismo e febre de inovação por parte dos jurisconsultos portuguêses.

Eesta diversidade de condicionalismos que reside, segundo cremos, a primeira e fundamental explicação das divergências que vão fazer-se notar, daí em diante, na evolução das instituições jurídico-privadas de Portugal e do Brasil.

\section{A inferência doutrinal dos jurisconsultos na evolução do direito privado português}

Falemos, primeiramente, do que se passou em Portugal.

A vitória das idéias liberais, que tão importantes reformas legislativas iria originar no domínio do direito político e do direito administrativo, na organização judiciária e no processo, no direito fiscal e financeiro, e noutros ramos do direito público, não introduziu, em Portugal, reformas de vulto no domínio do direito privado. Houve, sem dúvida, importantes reflexos privatísticos de certas reformas administrativas ou processuais, como, por exemplo, os que resultaram do decreto de extinção dos dízimos, da lei chamada de extinção dos forais, que tão duro golpe vibrou no regime dos emprezamentos, e das famosas Reformas 
Judiciárias de 1832 de 1836 e de 1841 . E houve também algumas reformas parciais que afetaram o regime desta ou daquela instituição juridico-privada, como, por exemplo, o decreto de Mousinho da Silveira, que abriu o caminho para a extinção dos vínculos, o decreto daquele mesmo estadista que fixou novas regras quanto à maioridade e emancipação, e quanto à tutela dos menores, o decreto do governo setembrista que criou o registo das hipotecas, a lei do duque de Palmela que reformou e regulamentou os prazos da coroa e facilitou a respectiva remissão, etc. Mas reformas de vulto, de amplitude comparável às do direito público, não as houve em Portugal, no domínio do direito privado, antes do Código Civil de 1867. O próprio Código Comercial de Ferreira Borges, promulgado em 1833, não representa nenhuma inovação profunda, pois como observa judiciosamente CoElHo DA Rocha, o seu autor apenas "compilou as mais providentes disposições dos Códigos das Nações Cultas da Europa, os quais já pela lei de 18 de agôsto de 1769 tinham sido declarados subsidiários, para suprir a falta de legislação pátria neste objeto".

Isto significa que a fixação de novos rumos, na evolüção das nossas instituições jurídico-privadas, no periodo que vai desde os começos do liberalismo até o Código Civil, vai ser obra, fundamentalmente, da atividade doutrinal dos jurisconsultos. $\mathrm{E}$ o que há de mais curioso, nessa atividade doutrinal, é, sem dúvida nenhuma, a forma hábil como foram aproveitadas as normas de interpretação e de integração de lacunas, legadas pela época do jusnaturalismo, para introduzir, com apôio nelas, as inovações de fundo individualista bebidas nos Códigos posteriores à Revolução Francesa.

Efetivamente, se não houve nesta época - como já fizemos notar — e ao contrário do que sucedeu na época anterior, uma forte disciplina filosófica para nortear o legislador na tarefa de reformar o direito privado, menos a houve capaz de determinar a fixação de novas regras. 
de interpretação e de integração de lacunas, de modo a imprimir, deliberadamente, um novo rumo à atividade da jurisprudência e da doutrina. Os juristas tiveram de contentar-se, a êste respeito, com as regras de hermenêutica que a época anterior tinha formulado, e tôda a habilidade esteve agora em saber dar um sentido novo aos seus dispositivos, adaptando-os a uma linha de pensamento muito diferente daquela que presidira à sua promulgação.

A lei da Boa Razão, os Estatutos pombalinos da Unniversidade, os assentos da Casa da Suplicação da época jusnaturalista, continuavam a ditar, em plena época liberal, as normas relativas à interpretação das leis e à integração das suas lacunas. Recta ratio e usus modernus continuavam a ser, portanto, as normas supremas a que os juristas deviam submeter-se, na sua atividade doutrinal. Simplesmente, essas expressões tinham perdido, quase por completo, o seu antigo significado, e eram utilizados, por vêzes, para defender pontos de vista novos, que noutros tempos teriam sido, com base nelas, abertamente condenados: a boa razâo vestia agora pelo figurino do individualismo liberal; e o uso moderno deixara de ser o jusnaturalismo dum Heineecius ou dum Stryck, para passar a ser, simplesmente, o abundante manancial do articulado dos Códigos individualistas, nascidos do ambiente doutrinário da Revolução Francesa.

E Manuel de Almeida e Sousa - mais conhecido pelo pseudônimo de Lobão - o primeiro jurisconsulto a utilizar os Códigos estrangeiros como expressão do uso moderno, e a preconizar a sua aplicação, em Portugal, como direito subsidiário, fundando-se na autoridade da lei da Boa Razão. A êle se deve, em grande parte, a difusão, entre nós, do conhecimento do Código Civil Francês. Gouveia Pinto, no Tratado dos Testamentos, utiliza pela primeira vez o Código da Prússia. E Correia Teles, no Digesto Português, faz uso constante dêsses dois Códigos, o mesmo sucedendo com CoELHO DA ROCHA, nas suas Irstituições, onde igualmen- 
te se utilizaram o Código austriaco, o da Sardenha e vários outros.

A licitude da utilização dêstes Códigos estrangeiros como subsidiário do nosso direito, a ninguém, então, oferece dúvida. Coelho DA RochA, - exprimindo, aliás, o sentir unânime da época - justifica-a em tom ingênuo e simplista, dizendo que os Estatutos da Universidade, assim como permitem averiguar o uso moderno das nações nos escritos dos seus jurisconsultos, por maioria de razão devem permitir procurá-lo nas suas leis. $\mathrm{E}$ afirma isto em termos de quem ignora, ou, pelo menos, nenhuma importância atribui ao fato de êsse uso moderno, referido nos Estatutos de 1772, ter um significado doutrinal e filosófico muito próprio, simbolizando todo o pensamento duma escola jurisprudencial, de que os Códigos individualistas se achavam, por vêzes muito distanciados.

Se nos lembrarmos, mais uma 'vez, da enorme amplitude que tinha, entre nós, o recurso ao direito subsidiário, por virtude da deficiência das Ordenações e da legislação complementar, e da enorme importância que possuíam os critérios de interpretação, perante leis deficientemente redigidas, poderemos logo ter uma visão apriorística dos resultados práticos que derivaram desta franca aceitação, entre nós, do preceituado em Códigos estrangeiros: - Foi tôda uma nova massa de disposições, que lentamente penetrou nos quadros da Ordem jurídica vigente, e que os nossos jurisconsultos procuravam conciliar, na medida do possivel, com o direito tradicional, quase sempre sem grande critério filosófico, mas com incontestável mestria de ordem técnica - ou êles não fôssem, como realmente eram, juristas de primeira plana.

Importa, porém, não exagerar o papel inovador que êstes Códigos estrangeiros desempenharam entre nós. Muitos preceitos tradicionais continuaram de pé, pois a doutrina dos códigos modernos, só por si, nada podia contra a letra expressa das Ordenações ou das leis que lhe serviam 
de complemento. E continuaram de pé, do mesmo modo, muitas doutrinas que a tradição juridica portuguêsa tinha introduzido por via interpretativa ou integrativa das leis vigentes, ou porque tivessem obtido definitiva consagração como costume praeter legem, ou porque não fôssem de todo divergentes das que os códigos modernos consagravam, relativamente aos mesmos assuntos.

O direito privado português apresentava-se, assim, nas vésperas da promulgação do Código Civil de 1867, como a "resultante" duma sobreposição ou estratificação de três camadas de correntes doutrinais, correspondentes a outras tantas épocas históricas, bastante diferenciadas umas das outras, mas conciliadas entre si, com bastante perfeição técnica, pelo esfôrço e engenho de algumas gerações de juristas: - Primeiramente, o fundo tradicional ou escolástico, formado pelas Ordenações, pela legislação extravagante anterior a meados do século XVIII, e pela massá imponente dos tratados dos nossos velhos praxistas. Em seguida, o contributo da época jusnaturalista, formado pela legislação da segunda metade do século XVIII e pelas inovações doutrinais introduzidas, à sombra dela, pelos juristas. E, finalmente, a legislação liberal, de inspiração individualista, e a avalanche dos preceitos importados dos Códigos estrangeiros, a título de direito subsidiário.

\section{O balanço da ação criadora da doutrina e da jurisprudência e seu remate no Código Civil de 1867.}

Se, no meio disto tudo, quisermos fazer um balanço do que foi a ação criadora da jurisprudência e da doutrina, neste espaço dum século que vai desde a lei da Boa Razão à promulgação do Código Civil português, e do contributo assim prestado pelos juristas para a formação do substrato doutrinário em que aquêle Código havia de assentar, poderemos distinguir, nessa atividade, três aspectos fundamentais: - e primeiro, o da formulação de novas interpretações, por vêzes antagônicas das que anteriormente 
dominavam, a respeito de textos legislativos que se mantinham plenamente em vigor. É o segundo, o de divulgação de novas doutrinas, em contradição aberta com as Ordenações, ou outras leis do Reino, pretendendo implantálas, a pretexto de que êsses textos legislativos tinham caído em desuso, ou pretendendo, ao menos, defendê-las de iure constituendo. E é o terceiro, finalmente, o da ação exercida no vasto campo em que o silêncio da lei remetia para o direito subsidiário. Mais que em qualquer outro dominio, conseguiam aqui os juristas, com ampla liberdade de movimentos, condenar idéias, regras e doutrinas que já tinham feito voga, e substitui-las por outras, mais consentâneas com as novas linhas do pensamento jurídico.

Procuremos ilustrar, com alguns exemplos, cada um dêstes aspectos da atividade dos nossos jurisperitos:

O primeiro aspecto que apontámos foi o da atividade interpretativa. A pretexto de mera interpretação, e utilizando os critérios a êsse propósito proclamados pela legislação pombalina, conseguiram os nossos juristas, por vêzes, introduzir inovações profundas no direito vigente.

Assim, por exemplo, a famosa regra romana da essencialidade da instituição de herdeiro, chave de todo o direito testamentário, sempre foi considerada pelos velhos praxistas como princípio vigente no nosso direito. Entendiase que estava consagrada em certo passo das Ordenações, que recorria ao expediente de pressupor uma instituição tácita para considerar válido, em determinado caso concreto, um testamento sem instituição de herdeiro. Se se sentiu necessidade de recorrer a êste expediente, é porque - dizia-se - se desejou em princípio, considerar essencial aquela instituição.

Mas a referida regra caiu em desgraça, com o advento da escola jusnaturalista; e tanto bastou para que os nossos juristas passassem a interpretar às avessas a citada passagem das Ordenações. Como a norma, agora, era a de interpretar as leis de acordo com a boa razão, e como a 
boa razão condenava a essencialidade da instituição de herdeiro, passou a entender-se que as Ordenações, sancionando, num caso concreto, a validade dum testamento sem instituição, baniam expressamente a velha regra romana.

Algo de semelhante aconteceu com outra conhecida regra do direito romano: a regra nemo pro parte testatus pro parte intestatus decedere potest, tão fértil de consequências jurídicas, em todo o campo do direito sucessório. As Ordenações diziam que "se um soldado instituisse alguém por herdeiro numa propriedade, ou noutra cousa", seria visto "morrer abintestado no restante de sua fazenda", "por ser concedido por privilégio aos soldados, que possam morrer em parte com testamento e em parte abintestado". Estas palavras eram a reprodução fiel da doutrina romana, que considerava o testamento militar uma excepção à regra "nemo pro parte"; e entendia-se, portanto, que as Ordenações, sancionando essa excepção, tinham querido igualmente sancionar a regra.

Condenada, porém, a regra romana pelas doutrinas jusnaturalistas, houve que forjar aqui uma nova interpretação. Começou a fazer-se finca-pé no preâmbulo da lei pombalina de 9 de setembro de 1769 , onde a regra "nemo pro parte" era censurada, como contrária à boa razão; e, embora se reconhecesse que essa simples censura, feita no preâmbulo ou relatório duma lei, não tinha, de per si, valor legislativo, entendeu-se que obrigava, pelo menos, a interpretar as Ordenações em sentido diverso. E assim se passou a afirmar - numa interpretação manifestamente forçada - que o fato de as Ordenações terem sancionado uma excepção à regra "testatus" não significava que tivessem querido sancionar a própria regra, pois para isso seria necessário que o tivessem dito expressamente, e não disseram.

Em matéria de substituições fideicomissiárias, tambẻm se deu uma curiosa viragem de interpretação, no respectivo texto das Ordenações. Esse texto parece permitir, com 
tôda a nitidez, que a substituição se faça sem limite de grau, pois diz expressamente que esta substituição se chama compendiosa "porque debaixo dum compêndio de palavras contém em si muitas substituições de diferente natureza". Mas o individualismo jurídico da época liberal mostra-se adverso à idéia das substituições sucessivas, dizendo que elas teriam "os inconvenientes dos morgados irregulares". E passa a defender-se a doutrina de que essas substituições não devem ser permitidas em mais dum grau, porque aquêle texto legal, ao exemplificar a forma por que a substituição se faz, não enumera senão um substituto, dizendo: "A forma porque se faz é esta: Instituo por meu herdeiro a Pedro; e quando quer que êle falecer. seja herdeiro Paulo"

Se, do campo do direito sucessório, passarmos ao das obrigações, encontraremos habilidades interpretativas congêneres. Assim, por exemplo, as nossas Ordenações, falando do contrato de empréstimo, dizem que o devedor fica constituído em mora se não restituir a coisa emprestada "ao tempo e prazo que lhe for posto. e não sendo declarado tempo, cada vez que o credor lha pedir". Isto parece ser a confirmação plena da doutrina romana de que a mora se conta automàticamente, ex re, quando há prazo assinado para o pagamento, e que só na hipótese de não haver prazo se conta desde a interpelação, ou ex persona. Mas o Código Civil Francês tinha proclamado doutrina diferente, considerando sempre essencial a interpelação, e só a dispensando na hipótese de se ter convencionado, expressamente, que a mora se contaria por mero efeito de não-cumprimento da obrigação, no fim do prazo estabelecido. Os nossos juristas da época liberal não hesitam em aceitar esta doutrina, argumentando, com manifesta sem-razěo, que a passagem das Ordenações não era bem explícita, e que se devia interpretar dessa maneira para favorecer os devedores. 
Não nos alongaremos em mais exemplos, pois não faz mister.

Passamos, assim, a considerar a segunda das formas de atividade já apontadas. Agora não se trata já de interpretar, de maneira diferente, textos legais cujo vigor se mantém; trata-se de defender doutrinas antagônicas, saltando por cima dêsses textos e dando-os como desusados, ou, quando tal não é possível, proclamando a necessidade de serem reformados de iure constituendo.

Exemplo bem nitido, a êste respeito, é o da exigência da boa fé na prescrição extintiva. $O$ texto das Ordenações era tão claro, ao formular êsse requisito, que juristas da craveira dum Melo Freire e dum Correia Teles não ousaram investir contra êle, apesar do à-vontade com que habitualmente sustentavam soluções arrojadas. Mas CoELHo DA Rocha, seduzido pela doutrina do Código francês, vence os últimos escrúpulos: como o preceito das Ordenações fundamentava a exigência da boa-fé na razão do pecado, o ilustre mestre conimbricense chama em seu apôio a lei da Boa Razão, para dar êsse fundamento como caduco, e para, em face disso, sustentar que o referido preceito se deve dar por"antiquado e sem execução", na parte em que exige a boa fé do devedor. E foi essa a doutrina que ficou prevalecendo entre nós, até ser expressamente consagrada, alguns anos mais tarde, pelo Código Civil.

E o mesmo CoelHo da Rocha, também, quem considera antiquada, na esteira de Melo FreIre - mas contra a opinião comum dos juristas - a exigência de juramento para que os pactos sucessórios renunciativos sejam considerados válidos - exigência que as Ordenações expressamente formulavam.

Antiquados se consideravam também - mas, aqui, em plena correspondência com as realidades práticas — todos os preceitos da Ordenações relativos à adoção e à adrogação, apesar dos esforços de Borges Carneiro para demonstrar que nada obstava a que continuassem a observar-se. 
Não menos curiosos são, porém, aquêles casos em que os juristas, sem se aventurarem a considerar desusados ou caducos os preceitos das Ordenações, no entanto os criticam e defendem a necessidade da sua modificação.

Neste aspecto, uma das inovações que mais apaixonava os juristas portuguêses da época liberal, e a que o Código Civil havia de dar realização, era a da compra e venda com efeitos reais - doutrinas que o Código de NAPOLEÃo tinha, pela primeira vez, sancionado, revogando ostensivamente a tradição romanística. Segundo o direito romano, o contrato de compra e venda (e o mesmo acontecia com os contratos similares) não operava, por si só, a transferência do direito de propriedade; essa transferência só se operaria pela traditio, isto é, pela entrega - real ou simbólica da coisa vendida. E' era essa a doutrina seguida explìcitamente pelas nossas Ordenações, e confirmada também por um alvará de 1810.

Com uma tão recente confirmação expressa, não ousavam os nossos juristas anteriores ao Código Civil defender o desuso ou a caducidade de tal doutrina; mas não cessavam de acentuar a maior justiça da doutrina do Código Civil Francês, ao prescrever que o direito de propriedade se transferiria por mero efeito do contrato, mostrando as diferentes consequências jurídicas que desta doutrina adviriam para a resolução de dois importantes problemas: o da venda da mesma coisa sucessivamente feita a dois compradores e o do risco da destruição da coisa vendida.

Outra inovação em que se fazia finca-pé, e que o Código Civil também atenderia, era a da manutenção do arrendamento, quando havia alienação do prédio arrendado. As nossas Ordenações consagravam a velha doutrina romana de que o comprador do prédio arrendado não seria obrigado a manter o arrendamento, podendo, portanto, despedir o locatário. Ninguém ousava considerar em desuso tal doutrina; mas a opinião dominante era a de que devia ser 
substituida, de iure constituendo, pela doutrina oposta, já perfilhada pelo Código francês e pelo Código da Prússia.

Em desfavor tinha entrado, igualmente, a doutrina romana da lesão nos contratos, e era com relutância que se aceitavam os preceitos das Ordenações que expressamente a consignavam.

Outro tanto acontecia com a restitutio in integrum, procurando-se interpretar, o mais restritivamente possivel, os preceitos legais que a sancionavam.

E os exemplos poderiam multiplicar-se.

A terceira e última forma de atividade inovadora dos nossos juristas foi aquela que se desenrolou no domínio do direito subsidiário. Aqui, gozavam êles duma liberdade muito mais ampla, tornando-se-lhes fácil substituir as correntes tradicionais por aquelas que lhes pareciam mais aceitáveis.

O domínio do direito sucessório é um campo fértil de exemplos dêste gênero. Introduzida, por via legislativa, a regra le mort saisit le vif, e banidas, por via interpretativa, as regras romanas da essencialidade da instituição de herdeiro e da incompatibilidade entre sucessão testada e intestada, os juristas ficavam com o campo livre para introduzir outras modificações radicais, na tradição jurídica portuguêsa.

Assim, por exemplo, como consequência direta da regra le mort saisit le vif, que o alvará de 9 de novembro de 1754, conforme vimos, tinha introduzido entre nós, começaram os nossos juristas a defender a transmissibilidade hereditária do direito de adir e bem assim a admissibilidade da ação subrogatória. Num e noutro caso, iam abertamente contra a tradição romana e contra o nosso antigo direito.

Segundo o direito romano, se o herdeiro morria sem aceitar a herança, essa faculdade não podia transmitir-se aos respectivos sucessores, precisamente porque a titularidade da herança só se adquire pela aceitação, e ninguém podia, portanto, abrir sucessão sôbre direitos de que não 
era titular. Mas com a nova regra de que o herdeiro adquire automàticamente, por morte do de cujus, a posse e propriedade da herança, a solução a defender deve ser a inversa. E assim passou a ser unânimemente entendido desde Melo Freire a Correia Teles, Gouveia Pinto e Coelho da Rocha.

Também, segundo o direito romano, não podiam os credores impugnar o repúdio da herança, que o devedor fazia para o prejudicar, A ação pauliana não era aqui aplicável, porque o devedor não empobrecia, neste caso, o seu patrimônio, já que não tinha, antes da aceitação, nenhum direito sôbre os bens da herança. Mas, com a regra le mort saisit le vif, a escola do usus modernus pandectarúm vê-se obrigada a sustentar que os credores ficam efetivamente prejudicados com o repúdio, e que, portanto, devem poder aceitar a herança em substituição do devedor. E assim nasce a ação subrogatória, que o Código francês, logo em seguida, sancionaria, e que, defendida entre nós por Lobão e Correia Teles, passaria ao art. ${ }^{\circ} 2040$ do Código Civil.

A condenação da regra "nemo pro parte testatus" acarretou, por seu turno, importantes inovações. Melo Freire, por exemplo, sustenta abertamente a validade da aceitação pro parte, ou sub conditione, por entender que aquela regra romana, agora condenada, constituía o único óbice a essas formas de aceitação. Mas essa doutrina é já combatida por Almeida e Sousa; e Coelmo da Rocha condena-a também, com fundamento no prejuízo que daí poderia advir para os credores e para os legatários. $O$ individualismo liberal conseguiu aqui, vencer o jusnaturalismo do séc. XVIII, e restabelecer a tradição romana, embora com novos fundamentos.

A instituição de herdeiro a termo, suspensivo ou resolutivo, era também condenada pelo direito romano, com base na regra "testatus". A opinião unânime passa agora a ser, entre os juristas, a de que essa forma de instituição 
é perfeitamente admissivel, doutrina que, no entanto, não conseguiu passar, no Código Civil.

$O$ direito de acrescer, que a tradição romana fundamentava na regra "testatus", quanto às heranças, e na vontade presumida do testador, quanto aos legados, é outra vítima das novas idéias, que nesta matéria dominavam. Melo Freire e Gouveia Pinto condenam-no totalmente, tanto entre herdeiros como entre legatários. LoBão e CoRreia Teles rejeitam-no nas heranças, mas não nos legados. E é preciso esperar por COElHo dA Rocha para o ver reabilitado, não com o antigo e absoleto fundamento da regra "nemo pro parte", mas com o argumento da vontade presumida do testador e, sobretudo, com o argumento da sua consagração nos Códigos modernos. Mais uma vez, o individualismo jurídico da época liberal levava, aqui, de vencida o jusnaturalismo do séc. XVIII, destronando uma das suas conquistas que aparentavam ser mais definitivas, e restabelecendo a tradição romana - ela própria individualista também.

Outra inovação dos jusnaturalistas - mạs esta inteiramente aceite pelos escritores da época liberal - é a que diz respeito à capacidade para ser instituido herdeiro ou legatário. Segundo o direito romano, exigia-se que essa capacidade existisse, tanto no momento da abertura da herança, como na ocasião de o testamento ser feito. Agora, passa a exigir-se apenas que exista essa capacidade no momento da morte do testador.

Não podemos alongar-nos, indefinidamente, na citação de mais exemplos, tanto mais que, noutros ramos do direito, êles são talvez mais numerosos ainda que no direito sucessório. E o que sucede, nomeadamente, no campo dos direitos de crédito, onde as inovações, a bem dizer, são em número interminável. Sobretudo em pontos de pormenor, em que a legislação pátria normalmente era omissa, os nossos juristas punham de parte, com grande à-vontade, as velhas opiniões dos praxistas, para adotarem os pre- 
ceitos que encontravam formulados nos Códigos estrangeiros de recente promulgação.

O Código Civil Português de 1867 é o remate natural e lógico dêste quadro que acabamos de descrever, com a agravante de que, para a sua redação, tinha o legislador o campo totalmente livre, sem encontrar as peias dos textos legais anteriores, que, até aí, tantas vêzes tinham feito estacar a febre de inovação e de progresso que dominava os nossos jurisconsultos. Redigido em pleno auge do liberalismo político e econômico, o Código Civil representa, assim, a mais acabada expressão do individualismo jurídico em Portugal, consignando a maior parte das inovações propugnadas pelos juristas da época, e ultrapassando até, não poucas vêzes, a expectativa deixada pela obra dêsses juristas.

\section{A evolução do direito privado brasileiro a partir da independência do Brasil}

Que se passava, entretanto, no Brasil?

Como já dissemos atrás, a evolução do direito privado brasileiro, depois de consumada a independência, teve de sofrer, em grande parte, a influência dum condicionalismo histórico semelhante àquele que orientou a evolução do direito português no mesmo período. Mas, mercê de circunstâncias várias, que já acima procurámos esboçar, a desorientação doutrinal e filosófica resultante da penetração das idéias liberais foi, no Brasil, acentuadamente menor que em Portugal. E a consequência mais saliente que dai resultou foi ter-se feito sentir no Brasil, muito menos que entre nós, a febre de inovações precipitadas, of erecendo-nos, ainda hoje, a nação brasileira um sistema jurídico-privado muito mais próximo da velha tradição portuguêsa, muito mais liberto de influências estrangeiras, que o próprio sistema jurídico vigente em Portugal!

Comeca logo porque, no Brasil, nas primeiras décadas de independência e de libēralismo, não houve reformas 
legislativas com tão amplos reflexos jurídico-privados como as que, em Portugal, na mesma época, se levaram a cabo. Introduziram-se, sem dúvida, importantes e urgentes reformas de direito público, nomeadamente no campo administrativo e judiciário. Em certos ramos dêsse direito, os legisladores brasileiros marcharam, até, na vanguarda dos portuguêses, como aconteceu, por exemplo, em matéria de direito penal, em que o Brasil conseguiu ter um Código, perfeitíssimo para a época, vinte e tal anos mais cedo do que nós. Mas o direito privado, em si mesmo, nem direta nem indiretamente recebeu, por via legislativa, alterações de grande vulto, se excetuarmos a importante reforma do direito comercial, levada a cabo com a promulgação do Código de 1850.

Conservado, assim, mais preso à tradição que o direito português no domínio legislativo, o direito privado brasileiro iria também desprender-se menos dela, no domínio da jurisprudência e da doutrina. Não quer isto dizer que o Brasil se mantivesse alheio à influência dos novos doutrinadores, ou à sedução da novidade dos Códigos europeus de recente data. Tal como entre nós, também as obras doutrinais e legislativās da moderna Europa iam no Brasil fazendo voga; e tal como entre nós, não faltava quem desvirtuasse o primitivo sentido das regras de interpretação e integração das leis fixadas na época pombalina, para dar guarida, através delas, a novas doutrinas de importação estrangeira. Aliás, a própria divulgação das obras portuguêsas dum Govveia Pinto, dum Coelho da Rocha ou dum Correia Teles, facilitava as coisas nesse sentido, e fomentava essa corrente, favorável à introdução de inovações jurídicas de fundo individualista. A atestá-lo claramente, está o fato de ter-se chegado a pensar, em 1851, na adoção do "Digesto Português", de Correia Teles, como Código Civil da Nação brasileira, o que não foi por diante por virtude do parecer desfavorável da Ordem dos Advogados, 
em resposta à consulta feita, nesse sentido, pelo Ministro da Justiça Matoso Câmara.

Mas, se tudo isto é certo, não é menos certo que se esboçou, desde cedo, uma salutar reação contra êsse critério de inovação indiscriminada, e foi nessa corrente que terçaram armas os nomes mais representativos da jurisprudência e da doutrina. A mais expressiva vitória desta corrente conservadora - vitória cujos reflexos jamais se apagariam, na posterior evolução do direito privado brasileiro - foi a publicação da famosa Consolidação das Leis Civis, da autoria de Teixera de Freitas, que a aprovação oficial, dada em 1858, elevaria quase ao nível dum verdadeiro código.

O caráter conservador da Consolidação obedecia, antes de mais nada, às próprias instruções dadas pelo Govêrno brasileiro ao seu autor: “A Consolidação — dizia-se no programa do Govêrno - será feita por títulos e artigos, em os quais serão reduzidas às proporções claras e sucintas as disposições em vigor. Em notas correspondentes, deverá citar a lei, que autoriza a disposição, e declara o costume, que estiver estabelecido contra, ou além do texto".

Mas o conservantismo da ordem governamental vinha ao encontro da própria maneira de pensar de TeIXeIra DE Freitas. No extenso prefácio da sua obra, critica severamente o abuso, a que tantos juristas se tinham acostumado, de se desviar, sem grandes escrúpulos, dos textos legislativos vigentes. Põe as culpas, em grande parte, à lei de 18 de agôsto de 1769, que expressivamente diz ter dado "largas ao arbítrio, com o título de boa razão", e acrescenta, depois, estas palavras significativas: "Tudo concorreu para que os nossos juristas carregassem suas obras de matérias estranhas, ultrapassando mesmo as raias dos casos omisos. As cousas chegaram a tal ponto, que menos se conhece e estuda nosso direito pelas leis, que o constituem, do que pelos praxistas, que o invadiram". 
E mais adiante, no mesmo prefácio, expõe ele mesmo o critério que presidiu ao seu trabalho: "Examinar as leis em seus próprios textos sem influência de alheias opiniões, comparar atentamente as leis novas com as antigas, medir com precisão o alcance de umas e outras; eis o laborioso processo, que empregado temos para conhecer a substância viva da legislação".

Não é, de resto, note-se bem, por espírito retrógrado ou por deficiente conhecimento das mais modernas codificações e obras doutrinárias, que Teixeira de Freitas se mostra tão ardentemente conservador, mas com base numa sólida preparação científica, que reiteradas vêzes põe à prova, ao discutir certas orientações inovadoras e ao expor as razões por que prefere, contra elas, as soluções tradicionais. Nem, aliás, o seu espírito conservador é tão intransigente, que não dê guarida, uma vez que outra, a alguma interpretação mais arrojada, ou a alguma inovação merecedora de ser acolhida por via integrativa.

Que êste conservantismo de TeIXeIra de Freitas não era uma atitude meramente pessoal, mas a expressão do sentimento dominante entre os juristas de maior craveira, nesses meados do séc. XIX, mostra-o claramente o relatório da "Comissão encarregada le rever a Consolidação das leis civis" pois é essa a nota dominante que aí se põe em destaque, para declarar que a obra é digna da aprovação e do louvor do Govêrno imperial.

Goradas as tentativas da segunda metade do séc. XIX para a feitura dum Código Civil, a Consolidação de TerxeIRA DE Freitas ficou a ser, até começos do século XX, a expressão mais autorizada do direito vigente no Brasil. Respeitada quase como um verdadeiro código, ela conseguiu impor, na jurisprudência e na doutrina, o prestigio da corrente conservadora, fazendo cair em desgraça, duma vez para sempre, várias inovações preconizadas pela corrente progressista, que o direito brasileiro, ao contrário do direito português, nunca mais aceitaria. 
Foi o prestigio assim alcançado pela corrente conservadora, que tornou possivel fazer-se ouvir, com tanta autoridade e tanto êxito, a voz da tradição, nos trabalhos preparatórios do atual Código Civil Brasileiro. Desde a lúcida inteligência e cultura dọ autor do projeto primitivo, que soube reformar sem demolir - dando realização às mais prementes aspirações do século, sem renegar a herança sagrada do passado - até à voz outorizada dum ANDrade Figueira, que soube chefiar, com mão de mestre, na Comissão Revisora, a corrente tradicionalista, contra os partidários das inovações radicais, tudo contribuiu para o Código Civil Brasileiro pudesse sair a público como um conjunto equilibrado e harmonioso, onde a tradição juridica portuguêsa se mantém bem viva, embora remoçada - liberta de velhos anacronismos e de antiquados preconceitos.

Como expressivamente diz Paulo Merêa, “o legislador brasileiro não teve dúvida em aproveitar-se largamente dos elementos que lhe forneciam as legislações civis mais recentes e perfeitas"; mas, "acima de tudo, pairou a preocupação de consolidar oficialmente, sob uma forma científica, a obra do passado - não as velhas Ordenações e os seus preceitos absoletos, mas a obra sôbre elas lenta e sàbiamente edificada, graças, à colaboração harmoniosa dos orgãos legislativos, da doutrina e da jurisprudência".

\section{A fidelidade do Código Civil Brasileiro à tradição jurídica portuguêsa}

Em consequência dos fatos acabados de apontar, o Código Civil Brasileiro constitui, em pleno século XX, uma expressão muito mais fiel de tradição juridica portuguêsa, do que o próprio Código Civil Português, promulgado quase 50 anos antes!

Efetivamente, quando se estabelece o paralelo entre os dois Códigos Civis e se procura fazer o balanço da influên- 
cia neles exercida pelo antigo direito português, a nota dominante que logo salta à vista é a da presença, no Código Brasileiro, de instituições, idéias e doutrinas de fundo tradicional, que o Código português rejeitou, para dar guarida - quantas vêzes precipitadamente - a outras, de importação estrangeira.

Sem pretendermos fazer uma enumeração completa - o que, além de difícil, tornaria demasiado extenso êste trabalho - não deixaremos de referir alguns dos exemplos mais elucidativos desta diferença de atitude entre os dois códigos lusíadas.

Logo no domínio dos princípios gerais, aparece entre os dois códigos uma diferença importante, quanto à relevância do êrro de direito. Enquanto o Código português, no art. $^{\circ} 659$, declara que o êrro de direito acerca da causa produz nulidade", consagrando assim a opinião de CoELHO da Rocha e Correia Teles, o Código brasileiro não toma em consideração essa modalidade de erro, fixando, sem nenhuma reserva, a doutrina de que "ninguém se escusa de cumprir a lei, alegando que não a conhece" e dando, assim, acolhimento à velha doutrina romana, que era também a defendida pelos nossos praxistas, e que parecia ser corroborada por certo passo das Ordenações.

Outro ponto em que o direito brasileiro manteve sempre uma intransigência inflexível e em que o direito português logo cedeu, com o Código Civil, à novidade vinda de França, foi o da insuficiência do simples acôrdo de vontades para produzir a transferência de direitos reaís. O Código Civil brasileiro continua a consagrar a velha tradição romana, que sempre foi também a tradição portuguêsa, de que o simples acôrdo de vontades, na compra e venda, na doação, e em contratos congêneres, apenas tem efeitos obrigacionais, e não pode, só por si, produzir a transferência da propriedade, para a qual é necessário que ao contrato venha acrescentar-se a entrega, real ou simbólica, da coisa que se pretende transferir. Esta regra, ar- 
dentemente defendida por Teixeira de Freitas na Consolidação, e várias vêzes confirmada, depois disso, por diplomas legislativos avulsos, havia de ser reafirmada em todos os projetos de Código Civil, com excepção do de Felícro pos Santos, e receberia o mais natural acolhimento no Código de 1916. O nosso Código Civil, diversamente, dando realização aos intentos dos juristas da época, que se haviam deixado seduzir pelo Código de NAPoleão, consignaria a doutrina contrária, despresando, assim, a tradição jurídica portuguêsa.

Escusado é acrescentar que esta diferença de atitudes entre o Código português e o Código brasileiro dá lugar a importantes diferenças na regulamentação concreta de vários problemas, como, por exemplo, o da transferência sucessiva da mesma coisa a dois adquirentes, o da venda de coisa alheia, o do risco pela perda ou deterioração da coisa transferida, etc.; e em todos êsses problemas se faz sentir o mesmo apêgo da tradição por parte do Código brasileiro, a contrastar com o caráter inovador do Código português.

No domínio concreto do contrato de compra e venda, há outras diferenças ainda a assinalar, como, por exemplo, a que diz respeito à chamada retrovenda ou venda a retro. Condenada pelo art. ${ }^{\circ} 1587$ do Código português, nunca ela deixou de ser aceita no direito brasileiro, segundo a tradidição das Ordenações Filipinas, obtendo consagração no art. $^{\circ} 1141$ do Código de 1916.

No contrato de locação , o Código Civil brasileiro respeitou o preceito das Ordenações, que autorizava o despedimento do locatário quando a coisa era alienada, a não ser que o contrário se tivesse convencionado no contrato. Esta doutrina, que o nosso antigo direito tinha ido buscar diretamente ao direito romano, foi posta de parte pelo Código Civil português, no art. $^{\circ} 1619$, dando satisfação ao que tinha já sido proposto por Correia Teles, no Digesto Português, na esteira do Código de Napoleão e do Código da Prússia. 
Diferença fundamental entre os dois Códigos é também a que se nota, a propósito da boa fé, na prescrição aquisitiva. A doutrina expressa das Ordenações Filipinas, inspirada diretamente no direito canônico - doutrina essa, aliás, que os nossos escritores da primeira metade do século XIX não contraditavam - era a de que a boa fé se exigia durante tọdo o tempo da prescrição. O Código Civil português desviou-se dessa regra, e copiou o preceito do Código francês, que tinha restaurado, neste ponto, a doutrina romana, exigindo apenas a boa fé no momento inicial. O Código brasileiro, pelo contrário, no seu art. $^{\circ}$ 551, continua a respeitar a velha tradição portuguêsa.

Outro ponto em que o Código brasileiro respeitou a doutrina das Ordenações, que se tinha tornado obsoleta em Portugal ainda antes do Código Civil, e que êste, portanto, passou em silêncio, foi quanto ao contrato de adoção ou filiação artificial.

Deveras notável, igualmente, pelos reflexos de ordem prática que tem, é a diferença de critérios entre o Código brasileiro e o Código português, quanto ao cálculo da quota disponível, para efeito de redução de doação ou deixas inoficiosas, matéria em que, mais uma vez, o Código brasileiro respeita a tradição pátria e o Código português a renega. Segundo o $\S 10^{\circ}$ do art. ${ }^{\circ} 1790$ do nosso Código Civil, para efetuar aquêle cálculo, "somar-se-á o valor de todos os bens que o autor da herança houver deixado, feita a dedução das dívidas da herança; ajuntar-se-á à soma restante o valor dos bens que o falecido houver doado, e a quota disponivel serả calculada com relação a esta soma total". 0 art. $^{\circ} 1722$ do Código Civil brasileiro segue, porém, a velha tradição portuguêsa, estabelecendo que a metade disponivel se calcula "sôbre o total dos bens existentes ao falecer o testador, abatidas as dividas e as despesas do funeral". E, para evitar quaisquer dúvidas, o $\S$ único do mesmo artigo acrescenta que se calculam as legitimas "sôbre a soma, que resultar, adicionando-se à metade 
dos bens que então possuía o testador, a importância das doações por êle feitas aos seus descendentes". As doações feitas a estranhos não tem que ser aqui consideradas, dispondo o art. $^{\circ} 1176$ que elas só serão nulas na parte "que exceder a de que o doador, no momento da liberdade, poderia dispor em testamento".

Os institutos jurídicos abolidos pela codificação brasileỉra e antes pela portuguêsa

Ao lado dêstes e de vários outros casos, em que o Código Civil brasileiro se manteve fiel à tradição jurídica portuguêsa, e em que o Código português a renegou, não faltam exemplos de doutrinas e preceitos tradicionais que, embora banidos pelo Código português, conseguiram sobreviver no Brasil até ao Código Civil de 1916, e que só êste modificou ou pôs de parte. São pontos, portanto, em que os dois sistemas jurídicos hoje coincidem; mas em que a tradição portuguêsa conseguiu sobreviver, no Brasil, cincoenta anos mais em que Portugal.

Foi o que aconteceu, nomeadamente, com o benefício da restitutio in integrum, pelo qual podiam os incapazes, os ausentes e certas pessoas coletivas requerer a anulação dos contratos, embora vàlidamente celebrados, de que resultasse para êles prejuízo. Êsse benefício, que o Código Civil português totalmente afastara, nos artigos 38 e 297, conseguiu manter-se no direito brasileiro, com a regulamentação que tinha nas Ordenações. Foi só o Código Civil de 1916, no seu art. ${ }^{\circ} 8^{\circ}$, que veio acabar com êle, satisfazendo, aliás, uma instante aspiração da jurisprudência e da doutrina.

Nos mesmos têrmos, a doutrina romana da lesão nos contratos, encarada já com certo desfavor nas obras dos nossos juristas da época liberal, e rejeitada já para os contratos comerciais pelo Código Ferreira Borges, de 1833, veio a ser banida no Código Civil português, ressalvando-se 
apenas a hipótese de a lesão ter envolvido êrro, capaz de ser atendido como vício do consentimento. No direito brasileiro, pelo contrário, embora afastada, também, para os contratos comerciais pelo Código de 1850 , essa doutrina subsistiu até o Código Civil, tendo sido rejeitada nos trabalhos da comissão revisora, com a supressão do capítulo que, no projeto primitivo, se lhe referia.

Foi só, também, com a promulgação do Código Civil que o direito brasileiro admitiu a prescrição trintenária de má-fé, já consagrada em Portugal, desde 1867. Segundo as Ordenações, o fato de a posse ter atingido 30 anos fazia presumir a existência de justo título - presunção que, para prazos menores, não existia -; mas, quanto à boa fé, havia apenas, qualquer que fôsse o prazo, uma presunção tantum juris, que poderia sempre ser elidida por prova em contrário. Isto significa que o possuidor de má fé, nem mesmo ao fim de 30 anos adquiria por prescrição, desde que o proprietário da coisa conseguisse provar essa má-fé. Foi o Código Civil francês, que primeiro estabeleceu juris et de jure, em favor do possuidor trintenário, uma presunção de boa fé, doutrina que o Código Civil português copiaria. No Brasil, porém, subsistiu o direito tradicional, e foi só o Código Civil, no art. $^{\circ}$ 550, que fixou uma doutrina idêntica à do Código português e do Code Napoléon.

Na mesma ordem de idéias, foi só o Código Civil que, no Brasil, afastou a doutrina romana dos pecúlios como foi só êle que acabou com o testamento nuncapativo; e como foi só êle, ainda, que expressamente outorgou à mãe o exercício do poder paternal, na falta do pai - doutrina esta, aliás, já consagrada na prática. Tôdas essas inovações tinha-as introduzido, em Portugal, o Código Civil de 1867, afastando a tradição das Ordenações, que assim conseguiu sobreviver no Brasil mais meio século que entre nós. $\mathrm{E}$ os exemplos poderiam ainda prolongar-se. 
O paralelismo das inovações e das tradições na evolução do direito privado de Portugal e do Brasil

Nem tudo, porém, são diferenças, na evolução do direito português e do direito brasileiro, desde que se autonomizaram um do outro. Pelo contrário, há várias inovações, que ambos os sistemas jurídicos aceitaram concomitantemente, há tradições jurídicas a que ambos os direitos se mantiveram e mantêm fiéis, apesar dos ventos adversos que, em determinada altura, por vêzes, contra elas sopraram.

Exemplo frisante do primeiro caso é a doutrina que dispensa a boa fé na prescrição extintiva. Apesar da letra expressa das Ordenações em sentido contrário, a argumentação de CoelHo dA Rocha - já acima explanada conseguiu criar adeptos, tanto em Portugal como no Brasil, e o preceito das Ordenações passou a ser dado como caduco. Teixeira de Freitas consagra a nova doutrina, na Consolidação das Leis Civis, afirmando que ela era já, nessa data, a doutrina corrente no Brasil. E o Código português, poucos anos mais tarde, deu-lhe a sanção oficial para o nosso país.

Evolução idêntica foi também a que ambos os direitos sofreram, por virtude do abandono que se faz, desde a época do jusnaturalismo, das velhas regras romanas de direito sucessório. As consequências já assinaladas da adoção da regra le mort saisit le vif, e do abandono da regra "nemo pro parte testatus", fizeram-se sentir, com uma evolução semelhante, no direito português e no direito brasileiro; e ainda hoje os Códigos Civis das duas nações lusíadas fixam regras idênticas quanto à determinação do momento em que se adquire a titularidade da herança, quanto a transmissão hereditária do direito de adir, quanto ao exercício da ação subrogatória, quanto ao momento a que deve referir-se a capacidade de suceder, etc.

Mais significativas, porém, que estas inovações, simultâneamente aceites pelo direito português e pelo direito 
brasileiro, são as instituições juridicas tradicionais, a que os dois direitos se mantiveram sempre fiéis. Algumas delas são de tão transcendente importância, que seriam suficientes, só por si, para individualizar o direito luso-brasileiro como expressão dum tronco juridíco comum. É o que acontece com a adoção do regime da comunhão absoluta de bens, como regime matrimonial supletivo - tradição portuguêsa e cristã, hoje abandonada pela legislação de quase todos os países, mas a que Portugal e o Brasil mantêm plena fidelidade. É o que acontece, igualmente, com a exigência da outorga da mulher, para a alienação de quaisquer bens imobiliários do casal, sem excetuar os que são propriedade exclusiva do marido - outra tradição tìpicamente portuguêsa, que hoje constitui, que nós sabemos, caso único em tôdas as legislações do mundo. E é o que acontece, igualmente, na ordem da sucessão legitima, sobretudo no que respeita à preferência total dos ascendentes sôbre os colaterais - tradição romana pre-justinianéia, que se conservou no direito hispânico através da legislação visigótica, e contra a qual nada pôde o renascimento do direito romano justinianeu.

Mas além disto, em muitos outros pontos de menor importância, há no direito português e no direito brasileiro um nunca acabar de exemplos de fidelidade à tradição, e alguns dêles bem significativos, porque representam uma vitória duramente alcançada, em luta contra as inovações, de inspiração estrangeira, que os doutrinadores pretenderam introduzir.

Foi em vão, por exemplo, no campo do direito sucessório, que os nossos juristas do usus modernus e da época liberal atacaram o direito de acrescer e sustentaram a validade da instituição a termo e da aceitação pro parte. Direito português e direito brasileiro permaneceram fièis à tradição.

Foi em vão, igualmente, que se propugnou pela adoção da doutrina do Código Civil francês, quanto à mora no cum- 
primento das obrigações. As regras fixadas no Código português e no Código brasileiro são, ainda hoje, as do direito romano e do antigo direito das Ordenações.

Foi em vão, do mesmo modo que se pretendeu introduzir, em matéria de reivindicação mobiliária, a regra francesa "en fait de meuble possession vaut titre". Direito português e direito brasileiro continuam a rejeitar essa regra e a admitir o direito de sequela, tanto em relação aos imóveis como em relação aos móveis.

Para quê, citar mais exemplos? A longa exposição que já fizemos parece-nos suficiente para podermos concluir que Portugal e Brasil continuam a ser, no direito como em tudo o mais, duas pátrias irmãs, que se orgulham da sua ascendência comum, e que o Brasil mais ainda que Portugal, soube manter-se sempre fiel à velha tradição juridica lusitana, dignificando-a e rejuvenescendo-a, e dando, assim, um admirável contributo para a sua perenidade no mundo. 